\title{
MANDATORY AUDITOR ROTATION: THE PERCEIVED BENEFITS AND DRAWBACKS (A CASE STUDY IN BPK)
}

\author{
Putri Anggraini \\ Badan Pemeriksa Keuangan Republik Indonesia, Indonesia \\ putri.anggraini@bpk.go.id
}

\begin{abstract}
After years of implementation of the policy, there is an inconclusive opinion of whether a mandatory auditor rotation could improve the independence of auditors, including those working within the public sector, such as BPK. This study intends to empirically test the impact of mandatory rotation towards auditors' independence in fact and in appearance. Additionally, the study examines how auditor satisfaction towards the policy affects their perceived benefits and drawbacks of the scheme. Following a statistical assessment of primary data using the independent-samples t-test, findings show that independence in appearance of auditors would be enhanced as a result of mandatory rotation. The rotation policy, however, could not by itself improve auditors' independence in fact. Consequently, complementary schemes are required to preserve independence in fact of auditors. Further, auditors who have a favorable view of mandatory rotation would assume that the mechanism offers more advantages than disadvantages. On the other hand, unhappy employees would perceive that mandatory rotation brings more adverse effects than positive ones. The vast majority of res pondents also believe that the rotation mechanism is necessary to be implemented in BPK. Lastly, a number of valuable respondent inputs aimed to improve the rotation scheme are elaborated in this study.
\end{abstract}

\section{KEYWORDS:}

Mandatory rotation; benefits; drawbacks; independence; BPK 


\section{INTRODUCTION}

Since independence is the cornerstone of the auditing profession, it prompts auditors to act with integrity and objectivity in conducting an audit (Chiang, 2016). Dattin (2017) states that various means can be utilized to preserve and enhance auditor independence. One such means is the mandatory auditor rotation.

Previous studies have identified several reasons why mandatory auditor rotation is necessary to maintain auditor independence. Firstly, excessive audit fees can undermine auditor independence (Anis, 2014; Chiang, 2016; Ottaway, 2014; Roy, 2015). Chu and Hsu (2018) also Roy (2015) assert that the higher a commission represent the total income received by the audit firm, the more reliant they become to the client. This situation may lead auditors to submit to the client's demands (Al-Khoury, Ali, Al-Sharif, Hanania, Al-Malki, \& Jallad, 2015; Anis, 2014; Chiang, 2016; Chu \& Hsu, 2018). With the intention of retaining such clients, auditors would provide an unqualified opinion despite the substandard quality of the company's financial statements. Consequently, the audit quality would be compromised as the auditor would not be able to maintain their professionalism and objectivity during the audit.

Secondly, the provision of non-audit services would negatively influence auditors' decisions and independence (Chu \& Hsu, 2018; Ottaway, 2014; Roy, 2015). Chu and Hsu (2018) also find that auditors may need to maintain their reputation once they deliver non-audit services to their clients. Nagy (2008) and Roy (2015) claim that sometimes auditors are required to provide services which are not related to audit procedures such as designing clients' internal control system. Subsequently, when auditors from the same audit firm are required to audit the service output of their colleagues, they could compromise their independence since they have an interest in preserving the prestige of their firm by stating that the operating system is well designed. Consequently, this situation may harm the quality of audit reports. Thirdly, an unlimited duration of a relationship between an auditor and his client could potentially endanger auditor independence (Al-Khoury et al., 2015). Scholars believe that the longer excessive "coziness" between auditor-client transpires, the higher the possibility the auditors would become overly loyal to the client and disregard their professional skepticism in conducting an audit.

Moreover, the mechanism to appoint auditors can be a threat to the independence of auditors (Ottaway, 2014). Roy (2015) suggests that if management is allowed to be involved in the appointment process of auditors, they would be able to intimidate the auditors into providing an audit opinion on its behalf. Once the management could influence auditor independence, the audit procedures would be meaningless and the audit result would be untrustworthy. Roy (2015) also questions the effectiveness of the audit committee's role in the auditors' appointment procedure. The audit scandal in India involving Satyam Computer Services Ltd, occurred due to the fact that some members of the audit committee received gifts and incentives from the management. To return the favor, the audit committee recommended an audit firm favored by the management.

Given these situations, auditors need to maintain their independence by implementing mandatory auditor rotation (Dattin, 2017). Particularly in the public sector, auditors should uphold accountability and transparency by reporting their use of state's financial resources to stakeholders or the public (Loke, Ismail, \& Fatima, 2016). Scholars also argue that it is crucial for the public or taxpayers to understand that the government 
is under the obligation to use government financial appropriately towards enhancing the welfare of the people.

Nevertheless, in conducting an audit, public sector auditors may exercise professional judgments in making certain decisions (Sinason, 2000). Consequently, auditors should have an independent mindset and avoid any bias to be able to make decent decisions and report the audit results professionally to the public. Mandatory auditor rotation, therefore, may be necessary to be implemented for auditors who work in the public sector.

In Indonesia, public sector auditors are divided into two categories internal auditors known as Government Internal Supervisory Apparatus (Aparat Pengawasan Internal Pemerintah, APIP), and external auditors of the government. The role of external auditor is undertaken by The Audit Board of The Republic of Indonesia (Badan Pemeriksa Keuangan Republik Indonesia, BPK). As rotation and authority among the two categories of auditors are significantly distinct from one another, in this study the author will mainly focus on BPK.

Results of previous studies show that implementation of mandatory auditor rotation may be more suited to private sector auditors better than their public counterparts, especially in the BPK. The first argument for such an assertion is that BPK auditors do not receive remuneration or collect fees from the clients; consequently, they would not rely financially on the auditees. Furthermore, BPK auditors are prohibited from providing non-audit services to clients (BPK RI, 2018). As such, state auditors would not find themselves auditing their own work for the clients. Lastly, as mandated in the 1945 Constitution, the BPK has the right and obligation to audit the use of public funds in Indonesia. Therefore, the BPK audits the financial state- ments of all governmental institutions in Indonesia without having to rely on any appointment process of the clients.

These considerations in turn raise a question of whether a mandatory auditor rotation for public sector auditors merely serves as a complementary and non-compulsory tool to improve auditor independence. This study aims to answer this issue from the perspective of BPK auditors. Additionally, after years of implementation, it may be necessary to revisit the rotation mechanism in BPK to comprehend any contention that the auditors may have as the subject of the policy. Therefore, the first research question in this study is: has mandatory auditor rotation improved the independence of BPK auditors?.

Following years of implementation of the mandatory rotation, there are still conflicting opinions as to whether mandatory auditor rotation has brought more beneficial impacts on auditors than adverse ones (Dattin, 2017). Controversial outcomes from mandatory auditor rotation have likely arisen from difficulty in finding direct evidence by which to measure the impacts of such policy (Dattin, 2017). Dattin also believes that no fixed standard could be used worldwide in measuring the effect of the system. Therefore, the results of mandatory auditor rotation depend on where the rotation is analyzed and what attributes are utilized. Thus, it is essential to enrich existing literature on how crucial it is to implement mandatory auditor rotation since evidence to corroborate the assertion needs to be collected from diverse environments.

Previous research, then, use distinct attributes in assessing the impacts of the implementation of mandatory auditor rotation. Some studies apply financial proxies, namely: discretionary accruals (Al-Thuneibat, Issa, \& Baker, 2011; Nicolaescu, 2014); earnings quality (Chu \& Hsu, 2018); the cost of equity 
capital (Fernando, Abdel-Meguid, \& Elder, 2010) or earning response coefficient (Nicolaescu, 2014). Other research use qualitative measures, such as the number of audit findings (Komalasari, 2016); auditor size (Fernando et al., 2010); auditor expertise and experience (Al-Khoury et al., 2015; Boon, McKinnon, \& Ross, 2008; Fernando et al., 2010) as well as the perceived relationship between auditor and client (Al-Khoury et al., 2015).

To the author's best knowledge, no prior study has evaluated auditor satisfaction as an element in assessing the benefits and drawbacks of the obligatory auditor rotation. On the other hand, auditors' notion, regarding the rotation scheme, should be taken into account since they are in the position to determine whether mandatory rotation mechanism is beneficial for the stakeholders.

Also, Herzberg's two-factor theory explains that employees' satisfaction would affect their motivation and performance (Alfayad \& Arif, 2017). One of the main factors influencing employee satisfaction is the company's policy and administration (Herzberg, 1959 as cited in Smerek \& Peterson, 2007), including the rule of mandatory auditor rotation. The author, therefore, will gauge auditor satisfaction of compulsory rotation policy in order to assess their perception of the advantages and disadvantages of the system. Furthermore it is likely that studies about compulsory auditor rotation in the private sector outnumber research in the public or governmental sector. With this in mind, this study intends to supplement existing literature on the impact of obligatory rotation on public sector auditors, especially at BPK. It is hoped that policymakers take into consideration the result of this study as input in the redesign of the scheme of auditor rotation, which would increase auditor independence as well as enhance their satisfaction, leading to better performance. These facts generate the second and third research questions of this study: how does auditor satisfaction help identify perceived benefits and drawbacks of mandatory auditor rotation from the perspective of auditors at BPK; and would the benefits of compulsory auditor rotation outweigh its disadvantages in BPK, or whether the opposite is true, based on the view of $B P K$ auditors?

This study is expected to contribute to the literature on how mandatory auditor rotation could affect auditor independence in fact and independence in appearance by providing empirical evidence on the impact of obligatory rotation scheme in a public sector institution, BPK. Moreover, the study explains how auditor satisfaction determines the perceived benefits and drawbacks of the rotation scheme in the public sector.

In this regard, this study will be structured as follows; first, it will begin with some relevant research on mandatory auditor rotation while highlighting some of the benefits and drawbacks of the system. Secondly, it will provide an overview of the mandatory auditor rotation scheme at BPK. The author will then elaborate on how auditor satisfaction can affect their perception of the impact of the rotation scheme. Fourthly, the author will examine data gained from the respondents using statistical analysis as well as discuss the results.

\section{LITERATURE REVIEW}

\section{The Impact of Mandatory Auditor Rotation}

The public consider auditors as 'guardians of trust', as they have the capability of producing reliable audit reports to feed into the decision making process (Ottaway, 2014; Roy, 2015). Independence is one of the vital foun- 
dations for auditors to aid a fair financial statement (BPK RI, 2018; Roy, 2015). Ottaway (2014) states that there are two forms of auditor independence, namely: independence in fact and independence in appearance. The former permits auditors to act in an independent state of mind, allowing individuals to audit with integrity, objectivity and professional skepticism. The latter means auditors ought to avoid any circumstances where third parties could interfere with their honesty and objectivity in conducting audits. Therefore, auditors should not only ensure the reliability of audit reports by personally holding ethical values but also take into account the public trust that they are independent.

However, an unlimited auditor tenure could impair auditor independence since objectivity and skepticism of auditors would decline over time (Al-Khoury et al., 2015; Mautz \& Hussein, as cited in Dattin, 2017). Al-Khoury et al. (2015) and Ottaway (2014), additionally, state that the "over-cozy" relationship between auditor and client is likely affecting the lack of inquiry and innovation in undertaking the audit. Moreover, the quality of the audit report could be decreased since the long tenure creates an "over-familiarity" for auditors (Al-Khoury et al., 2015; Dattin, 2017; Ottaway, 2014). This is when auditors could not objectively and creatively perform audit procedures and collect audit evidence. They would merely conduct the audit based on their previous experience and make unjustified assumptions instead of objectively evaluating the evidence. The tedious audit process would not be effective in detecting misstatement in financial reports.

Additionally, the infamous audit failures occurring in early 2000, such as the EnronAndersen scandal, were a wake-up alarm within the accounting community. The financial catastrophe has reopened concerns over the importance of auditor rotation in maintaining independence and improving audit quality (Anis, 2014). Since then, some authorities around the world have started to set up regulations aiming to force firms to rotate their auditors after a certain engagement period. Some of these regulatory instruments are the Sarbanes-Oxley Act (SOX) of 2002 in the US, the EC agreement 2014 in Europe, and the Corporation Act 2001 in Australia (Ottaway, 2014). The SOX of 2002 defines obligatory auditor rotation as a mechanism to restrict the period of tenure between auditors and clients (Harris \& Whisenant, 2012). Thus, an auditee's financial statement must be audited by different auditors after a certain period of audit tenure.

After its implementation over these years, however, mandatory auditor rotation remains a debatable topic among scholars and professionals. Some benefits and drawbacks of compulsory auditor rotation have been identified. Some of the perceived advantages of mandatory auditor rotation are improved auditor independence and bring fresh eyes.

As highlighted above, a long-standing relationship between auditors and clients could impair auditors' independence in appearance. In this regard, Anis (2014) and Ottaway (2014) argue that forced rotation of auditors would increase public perception of auditor independence since public faith in the reliability of financial reports depends on their impression that the external auditors are free from personal bias and third party's influence. Moreover, the compulsory rotation of auditors would strengthen their "independence in fact". The limited tenure of auditors would reduce pressure on them to be loyal to the auditees or lessen their dependency on incentives from clients to maintain the audit engagement. Thus, the auditors would be more willing to challenge management's accounting policy as well as investigate other financial issues. Ottaway (2014) 
also asserts that the interests of clients and auditors would no longer be aligned because of forced rotation policy. Consequently, the eagerness of auditors to acquiesce to and satisfy their clients would be lower (Dattin, 2017).

Mandatory auditor rotation would allow "fresh eyes" to audit a client's financial statement after a certain period of audit engagement (Al-Khoury et al., 2015; Dattin, 2017; Ottaway, 2014). Scholars contend that the new points of view brought by auditors in an audit are necessary as they would be more creative in setting up an audit program. The newly involved auditors may be able to detect and report misstatements, which could not be found by the original auditors (Lennox, 2014). The system, consequently, would be a safeguard against the "familiarity threat" caused by the extended period of an auditor-client relationship.

The mandatory auditor rotation is also a watchdog mechanism. The mechanism of changing auditors after a certain period of audit engagement would promote diligence and conscientious decision-making by auditors because they would become aware that their current job would be judged by the "fresh-eyes" when their tenure is over (Ottaway, 2014). Accordingly, Al-Khoury et al. (2015) suggested that the current auditors needed to maintain their prestige and reputation toward clients and the public; thus, they would conduct the audit carefully by complying with the auditing rules and standards. A study also found that auditors were likely to report more material misstatements if the rotation scheme was obligatory than when the auditor-client relationship was not constrained by the mandatory rotation system (Ottaway, 2014).

The mandatory rotation could be an incentive for auditors, as Al-Khoury et al. (2015) argued that this would allow auditors to ex- perience new challenges and gain new knowledge when they audited other clients. Instead of auditing the same clients over a course of years, auditors would have opportunities to meet new clients from distinct industries after an audit engagement ended. Moreover, mandatory auditor rotation could not only strengthen their independence but also their skepticism in conducting an audit (Chiang, 2016). The scholar contends that independence is a fundamental antecedent to professional skepticism; an attitude that would lead auditors to improve audit quality. The rotation scheme may also help auditors avoid boredom at work as well as create a comfortable and conducive working environment (BPK RI, 2010).

Nevertheless, the opponents of mandatory auditor rotation argue that the scheme would cause adverse effects, such as a limited impact on independence in fact. Ottaway (2014) argues that despite mandatory auditor rotation being implemented, clients still pay auditors' fees. The company can also replace the auditors even though their audit tenure has not concluded. Accordingly, mandatory rotation of auditors would not fundamentally change the issue of auditor-client relationship. Internal pressure is likely to continue as the auditors still need to "please" their clients, despite the enforcement of obligatory mandatory rotation of auditors.

Boon et al. (2008) state that auditors who maintain high ethical standards are likely able to produce high-quality audit reports since they are able to uphold their integrity. Besides, to ensure that the independence of auditors is not compromised, they should be made aware of ethical value and virtue of ethics whenever they make any decisions related to audit (Chiang, 2016). Thus, it is insufficient to ensure auditor independence by only implementing mandatory rotation.

Some say that mandatory rotation may in- 
crease the risk of audit failure, that mandatory rotation is a double-edged sword with regard to auditors' knowledge. Auditors are likely to have a higher understanding of their auditees due to their long tenure and experience in undertaking the audits and the expertise they accumulate over the years would allow them to criticize and question the management in preparing the financial statements (Ottaway, 2014). Moreover, upon undertaking their new tasks following a rotation, incoming auditors would have to experience a sharp learning curve related to the client's business. Consequently, many scholars believe that the significant disadvantage of mandatory auditor rotation is it would heighten the risk of audit failure and reduce audit quality, especially in the initial years of audit engagement (Al-Khoury et al., 2015; Dattin, 2017; Ottaway, 2014). The risk is likely due to the newly assigned auditors having a lack of knowledge and familiarity with the client's operational system.

Ottaway (2014) argues that mandatory auditor rotation would increase audit fees as a result of the incurred steep 'learning curve' as discussed above. Incoming auditors need to acquire the necessary knowledge of the new client; thus, they would be required to undertake orientation sessions to fill these gaps. Ottaway also explains that most audit firms would either pass the cost to the clients in the form of increased audit fees; or compensate by compromising their audit quality. Moreover, in the private sector, mandatory auditor rotation would also become a burden for the management and require more time and money to be expended by the audit committee as they have to take into account a strict selection process to appoint new auditors.

Another ground for criticism of mandatory rotation is that a limited duration of an auditor's tenure would discourage his/her investment in specialization and loss of knowledge/familiarity with specific clients within that particular industry (Ottaway, 2014). Auditors would tend to become generalists than specialists since they would be easily rotated to other clients, which would require different sets of expertise to undertake the audit. On the other hand, having a specific set of specialized knowledge would benefit the auditors as they would possess added-value and personal branding compared to their colleagues. Additionally, such specialization would increase auditors' performance in producing high-quality audit reports.

\section{Mandatory Auditor Rotation at BPK}

According to Article 2 of Law Number 15 of 2006, BPK is the sole supreme audit institution with the mandate to audit the use of the state's financial resources in Indonesia. $\mathrm{BPK}$, therefore, has the right and obligation to deliver an audit opinion on financial statements prepared by government institutions and agencies. The best audit opinion that can be given by BPK on a financial statement produced is an unqualified opinion. Such an opinion entails that the report is reasonably and appropriately presented, free from material misstatement, as well as in compliance with accounting standards (Tuovila, 2019).

Since an unqualified opinion is perceived as an accomplishment among government institutions in Indonesia, many of them strive to achieve the clean auditor's report (Anggraini \& Putra, 2018). It is critical, therefore, for the auditors to maintain their independence, integrity, and professionalism in conducting the audit (BPK RI, 2018), in order to render an objective audit opinion on a client's financial statement.

BPK is aware that the auditors are invaluable assets who enable the institution to perform its constitutional mandate. In addition 
to skills and expertise, independence is also a cornerstone of audits conducted by BPK auditors. The institution, consequently, has undertaken various measures to increase the independence of auditors, such as implementing a mandatory rotation. Accordingly, auditors at all levels, comprising of team member (Pemeriksa Pertama), team leader (Pemeriksa Muda), controller (Pemeriksa Madya) and audit partner (Pemeriksa Utama), should abide by the mandatory rotation requirement.

The clients of BPK are central and local government, state-owned and regional enterprises, the Central Bank, public service agencies, as well as other institutions that make use of the state's financial resources in Indonesia (Article 6 of Law Number 15 of 2006). The auditees' offices are located in all provinces in Indonesia. Therefore, aside from its head office in Jakarta, BPK has representative offices in each province to ensure that it can perform its mandate effectively.

Auditors at the head office are assigned to one of 8 (eight) departments, namely Directorate General of Audit (Auditorat Utama Keuangan Negara, AKN) I to VII and Directorate General of Investigative Audit (Auditorat Utama Investigasi, AUI) (BPK RI, 2017; Komalasari, 2016). In addition, there are 34 representative offices operated by BPK throughout the country (BPK RI, 2017). This allows auditors to be rotated: (1) between BPK representative offices in the different provinces in Indonesia; (2) between the head office in Jakarta and any of the representative offices outside Jakarta; or (3) certain units or AKNs within the head office. Arrangements described in (1) and (2) are the types of rotation that enable auditors to be transferred from one province to another. In this study, the author will focus on these types of rotation.

The mandatory auditor rotation in BPK is conducted pursuant to Decree of the BPK Secretariat General Number 366/K/XXIII.2/9/2010 about concerning Rotation of BPK Employees (Keputusan Sekretaris Jenderal Nomor 366/K/X-XIII.2/9/2010). Further, based upon Article 2 of Decree Number 366/K/X-XIII.2/9/2010, mandatory auditor rotation is intentionally implemented to manage the auditors' career development, maintain auditors' independence in conducting audits, combat boredom at work and create a comfortable and conducive work environment, meet the organization's needs as well as the employees' interest, and build expertise and performance of the auditors at BPK.

To achieve these goals, BPK has issued Decree Number 662/K/X-XIII.2/11/2013 concerning Rotation Arrangement at BPK (Keputusan Sekretaris Jenderal Nomor 662/ $\mathrm{K} / \mathrm{X}$-XIII.2/11/2013). The policy is intended to guarantee equity and transparency of the obligatory rotation scheme at BPK. Moreover, the regulatory instrument has been adopted to serve as a guideline for BPK's policymakers who are involved in the management of auditor rotation, helping them to share common views and perspectives in making decisions relating to the rotation of auditors.

\section{Auditor Satisfaction with the Rotation Scheme}

Employee satisfaction is the level of happiness and emotional response from workers to a type of existing situation in the office (Tso, Liu, \& Li, 2015). They also assert that satisfaction depends on personal evaluation and fulfillment of individual needs by the organization. Furthermore, Alfayad and Arif (2017) claim that job satisfaction is a form of how much workers like or dislike the job, including many factors around it. The author believes that it is a key element of appreciation that leads to a feeling of fulfillment. 
Alfayad and Arif (2017) argue that job satisfaction is one of the crucial elements to increase the employee's motivation in conducting their tasks. Arguably, when workers view their job with a favorable feeling, they will escalate their performance and are likely to work at the highest limit of their abilities.

In 1959 Herzberg established a dual-factor theory of motivators and hygiene factors that influence worker satisfaction (Smerek \& Peterson, 2007). Herzberg (1959), as cited in Alfayad and Arif (2017), explains that, firstly, the motivators are elements that directly related to doing a task such as achievement, recognition, promotion, nature of work, responsibility, and growth. The motivators will lead to job satisfaction; nevertheless, they do not increase the level of dissatisfaction. On the other hand, the hygiene factors are items associated with conditions surrounding the job, for instance, compensation, benefit, coworkers relationship, job security, as well as the company's policy and administration, including the mandatory auditor rotation system. The absence of hygiene factors would upsurge employees' dissatisfaction.

Therefore, it is crucial to take into account the satisfaction of auditors towards the implementation of rotation policy since a lack thereof would increase the level of their dissatisfaction with their job. Moreover, a satisfied employee would not jeopardize the principal values of an institution he works for (Tso et al., 2015). At BPK, the core values to be adopted by auditors are independence, integrity, and professionalism (BPK RI, 2018). If auditors are satisfied with the implementation of mandatory rotation, they will conduct audits independently and professionally, resulting in a reliable audit report. On the other hand, if auditors do not feel happy with the current working environment, they will resort to adverse behavior to assert their feelings, such as lowered output quality, distorted self- awareness, or even decision to quit the job (Tso et al., 2015).

Undeniably, many believe that auditors' satisfaction toward the rotation scheme would also affect their perception of the benefits and drawbacks of the system. It is likely that if an auditor is satisfied with the implementation of mandatory rotation, he will consider the benefits of the system outweighs the drawbacks. Some elements may affect auditor satisfaction toward the rotation policy. These include transparency, justice, and fairness of the scheme to all auditors at different levels. Tan and Lau (2012) emphasize that employees' perception of procedural fairness leads to better job satisfaction, which eventually influences the workers' performance in the long term.

Secondly, the location where auditors are transferred to under the rotation scheme may influence their opinion of the system as well. The preferred province of assignment may be different between auditors, as it involves personal choice or necessity. However, in most cases, the desired duty location or area for auditors is their region of domicile. Lastly, appropriate compensation given to the auditors upon being transferred to another province could increase their satisfaction level concerning the policy. The rewards could take several forms, such as financial incentives, a new conducive working environment, or opportunities for career advancement.

\section{RESEARCH METHOD}

The author will utilize purposive sampling in determining the targeted respondents for this study. The respondents, then, will be categorized into two groups. The first group will consist of auditors who have not been rotated during their working period in BPK or never experienced mandatory auditor rotation (MAR). These auditors are usually 
new employees who joined BPK in the early years of their career.

The second group, subsequently, will be a number of auditors who have been rotated (at least once) during their tenure. Furthermore, the rotation should take place in different provinces throughout Indonesia. An auditor who gets transferred from Jakarta Representative Office to South Sumatra Representative Office is an example of someone who meets the requirements to be a respondent for the study. Additionally, the author will not differentiate the career level of the auditors given that all of the auditors should adhere to the mandatory auditor rotation policy (BPK RI, 2010; BPK RI, 2013).

The author will then divide respondents of Group 2 into two categories. The first category consists of auditors dissatisfied with the implementation of the mandatory auditor rotation in the organization. The second category comprises of auditors who are pleased with the policy. Concisely, the respondents will be selectively grouped as presented in Table 1.

The author utilizes independent-samples ttest with the level of significance of 5 percent to respond to the research questions 1 to 3 . The independent sample t-test compares the means of two independent groups to determine whether there is statistical evidence that the associated population means are significantly different (Siregar, 2013). The independent-samples t-test is appropriate for this study as the writer intends to compare the primary data gained from two independent groups. In other words, the respondents in Group 1 will not be included in Group 2 and vice versa.

Responses given by the two groups of respondents (Group 1 and Group 2) relating to auditor independence will be compared to answer the first research question. Moreover, a statistical analysis will be conducted to determine whether auditor independence is different between the two groups of respondents using an independent-samples t-test. Subsequently, it will determine: (1) will the auditor's independence increase after they are being rotated or vice versa, and (2) which auditor's independence (independence in fact or independence in appearance will be more affected by the mandatory rotation system.

Only responses given by Group 2 will be used in answering research questions 2 and 3 . Since respondents in Group 2 are auditors who have experienced the rotation scheme first-hand thus, they may have received some benefits and may have encountered some challenges due to the scheme. Meanwhile, auditors in Group 1 are individuals who have not yet experienced mandatory rotation therefore they may comprehend the system based on general knowledge and information. In that regard, the author believes that the responses provided by Group 2 would reflect actual and noticeable facts concerning the positive and negative impacts of the mandatory rotation mechanism. The independent-samples t-test will also be used in answering the research questions 2 and 3 .

Table 1. The Group of Respondents

\begin{tabular}{cll}
\hline \multicolumn{1}{c}{ Respondents } & \multicolumn{1}{c}{ Criteria } & Research Question \\
\hline Group 1 & never experienced MAR & Research Question 1 \\
\hline Group 2 & have experience with MAR & Research Question 1 \\
\hline Category 1 & dissatisfied with the implementation of MAR & Research Question 2 \\
\hline Category 2 & satisfied with the implementation of MAR & Research Question 3 \\
\hline
\end{tabular}


After statistically testing data obtained from Group 2, this study will also assess auditors who are satisfied and dissatisfied with the implementation of mandatory rotations on whether they have different perceptions regarding the benefits and weaknesses set by the policy. In addition, it will be identified whether the benefits of the rotation scheme outweigh the disadvantages. Finally, some input for improvement given by respondents will be discussed in this study.

Consistent with Herzberg's duality theory of motivators and hygiene factors, it is expected that satisfied auditors will perceive mandatory auditor rotation as an exercise that is fairly and appropriately applied in the organization. Given that situation, these auditors consider that the benefits of the mandatory rotation scheme will outweigh the drawbacks and vice versa.

Primary data in this study is obtained by using two distinct questionnaires for respondents in Group 1 and Group 2. The questionnaires consist of both close-ended and open-ended questions have delivered from March to November 2019. A Likert scale is used to measure the respondents' answers related to the close-ended questions, by categories Strongly Disagree, Disagree, Neutral, Agree, and Strongly Agree. Consequently, both groups will address the same problems related to auditor independence. However, only Group 2 will be given questions related to auditor satisfaction toward the mandatory rotation policy as well as the benefits and drawbacks of the systems. The variables or issues presented to the respondents in the questionnaire for each group are elaborated in Appendix 1.

\section{RESULT AND DISCUSSION}

The total returned and valid questionnaires were 49 questionnaires for Group 1 and 53 questionnaires for Group 2. The respondents are auditors with varied experiences, roles, and responsibilities. They also come from different educational backgrounds, gender, and age. The information of the respondents in Group 1 and 2 is elaborated in Appendix 2. The independent-samples t-test with the level of significance at 5 percent is applied to answer research questions 1 to 3 .

\section{Could a mandatory auditor rotation improve the independence of BPK's auditors?}

Table 2 presents the output of the Independent-samples t-test to assess the improvement of auditor independence after they have been rotated to different BPK's regional offices. The result of Levene's for equality variances, which tests the homogeneity of variance assumption, shows that the $\mathrm{p}$-values for independence in fact and independence in appearance are each 0.081 and 0.758 . As both

Table 2. The Output of Independent-Samples t-test

\begin{tabular}{llccc}
\hline \multicolumn{1}{c}{ Variable } & \multicolumn{1}{c}{ Auditor } & $\begin{array}{c}\text { Levene's test for } \\
\text { Equality Variances } \\
\text { (Sig.) }\end{array}$ & $\begin{array}{c}\text { Sig. } \\
\text { (2-tailed) }\end{array}$ & Mean \\
\hline Independence in Fact & $\begin{array}{l}\text { Group 1 } \\
\text { (no experience of MAR*) } \\
\text { Group 2 } \\
\text { (experienced the MAR) }\end{array}$ & 0.081 & 0.073 & 11.88 \\
\hline Independence in Appearance & $\begin{array}{l}\text { Group 1 } \\
\text { (no experience of MAR*) } \\
\text { Group 2 } \\
\text { (experienced the MAR) }\end{array}$ & 0.758 & $0.001^{* *}$ & 13.06 \\
\hline
\end{tabular}


p-values are more than 0.05 , it can be assumed that the variances are equal, and the standard deviations are the same. Also, the author can further interpret the t-value and the significance level associated with the t-value.

The p-value of "independence in fact" is 0.073, which is higher than the level of significance of 0.05 (0.073>0.05); thus, there is no difference between the mean among the auditors who have no experience in the rotation mechanism (Group 1) and those who have been rotated (Group 2). As a result, the author does not further compare the mean between both groups since statistically there is no different mean between them. In other words, auditors' independence in fact would be the same despite having implemented the obligatory rotation.

On the other hand, the p-value of "independence in appearance" is $0.001<0.05$; therefore, statistically and significantly there is a different mean between both categories regarding their level of "independence in appearance". Related to auditors' independence in appearance, the Table 2 suggests that auditors who have been rotated (Group 2) have a slightly higher mean (15.53) compared to the respondents in Group 1 who have not yet been transferred to other BPK's representative offices (13.53). The outcomes show that there is an increase in auditors' independence in appearance after the mandatory rotation is implemented.

In conclusion, auditors perceived an increase in "independence in appearance" after they were transferred to different BPK's representative offices. Ottaway (2014), accordingly, argued that the mandatory rotation would raise public perception of auditor independence. The stakeholders of BPK would also assume that by conducting the mandatory rotation, auditors would be free from personal bias and adverse influence from the third parties. The increase of independence in appearance, additionally, would be necessary for BPK since the public would trust the credibility of the institution and rely on audit reports produced by the organization.

Auditors, nevertheless, assume that their "independence in fact" would not be different, although they have been rotated to various representative offices. The results also support the previous study from Ottaway (2014), who contended that mandatory rotation would neither improve auditors' independence in fact nor change the issue of auditor-client relationship. It is because auditors also should hold high ethical standards whenever and wherever they conduct audits (Boon et al., 2008). Consequently, the obligatory rotation solely would not be enough to ensure that auditors are ethically professional, which allows them to act in an independent state of mind with integrity and objectivity (Ottaway, 2014). The rotation policy should be complemented by other schemes to gain more independence in fact for auditors, such as optimizing code of ethics by conducting regular ethical training, strengthening internal control, and promoting a whistleblowing system.

\section{How does auditor satisfaction distin- guish the perceived benefits and draw- backs of the mandatory auditor rota- tion from the perspective of the audi- tors in BPK?}

The statistical result from independentsamples t-test in assessing research question 2 is presented in Table 3. The results of the Levene's tests for both categories are each 0.552 and 0.762 . The p-values are more than the level of significance of 5 percent; thus, the author can assume that the variances in both samples are equal. The author, subsequently, could interpret the t-value and the significance level associated with the t-value. Furthermore, sig. (2-tailed) of the perceived 
Table 3. The Output of Independent-Samples t-test

\begin{tabular}{llccc}
\hline \multicolumn{1}{c}{ Variable } & \multicolumn{1}{c}{ Auditor } & $\begin{array}{c}\text { Levene's test for Equality } \\
\text { Variances (Sig.) }\end{array}$ & $\begin{array}{c}\text { Sig. } \\
\text { (2-tailed) }\end{array}$ & Mean \\
\hline Benefits of MAR* & Category 1 (Dissatisfied) & 0.552 & $0.031^{* *}$ & 39.74 \\
& Category 2 (Satisfied) & & 42.86 \\
\hline Drawbacks of MAR & Category 1 (Dissatisfied) & 0.762 & $0.032^{* *}$ & 13.10 \\
& Category 2 (Satisfied) & & 11.59 \\
\hline
\end{tabular}

Notes: *MAR: Mandatory Auditor Rotation **level of significance at 5\% (two-tailed).

benefits of mandatory auditor rotation is 0.031, which is lower than 0.05 (0.031<0.05). It can be assumed that there is a statistically different mean between the auditors who are satisfied with the obligatory rotation policy and the ones who are not confident with the system related to their perceived benefits of the rotation scheme.

Related to the perceived benefits of the system, the mean of Category 1 or auditors who are dissatisfied with the policy implementation is 39.74. Category 2 (auditors who are confident with the rotation system) has a mean of 42.86, which is higher than the mean of Category 1 (42.86>39.74). In other words, auditors who are confident with the rotation scheme would perceive that the benefits of the rotation policy outweigh the drawbacks.

The p-value of the perceived drawbacks of mandatory rotation is 0.032 , which is lower than the level of significance $(0.032<0.05)$. This suggests that there is a statistically different mean between the two categories of auditors related to their perception of the drawbacks affected by the obligatory rotation. Given that the mean of Category 1 (13.10) is moderately higher than the mean of Category 2 (11.59) therefore, auditors, who are unhappy with the policy, consider that the rotation mechanism brings more adverse effects than the positive ones.

To sum up, auditors who are satisfied with the implementation of mandatory rotation policy in BPK would consider that the scheme brings more benefits than drawbacks. Contrarily, respondents who are uncomfortable with the system believe that the policy will negatively affect them and the institution rather than bringing advantages.

The finding is arguably a novel finding related to the perceived impacts of mandatory auditor rotation schemes for auditor satisfaction upon the policy. The outcome also statistically proves the presumption that the satisfaction of auditors towards the mandatory rotation policy would affect their notion and perception of its benefits and drawbacks. Therefore, a robust improvement related to the mechanism of auditor rotation, which heavily relies on their comfort, is noteworthy.

\section{Would the benefits of mandatory audi- tor rotation outweigh drawbacks in BPK or vice versa based on the notion of BPK's auditors?}

There are 22 respondents (42\%) who are satisfied with the implementation of BPK's mandatory rotation. Nevertheless, there are 31 respondents or 58 percent who are unhappy since they are moved to other offices. It shows that more auditors are dissatisfied with the policy compared to those who are comfortable with the rotation scheme. The data is shown in Table 4.

Although the vast majority of respondents (58\%) are dissatisfied with the implementation of mandatory rotation, 74 percent of them assert that the implementation of mandatory rotation in BPK is necessary consider- 
Table 4. Categories of Respondents in Group 2

\begin{tabular}{ccc}
\hline Category & $\begin{array}{c}\text { Number of } \\
\text { Respondent }\end{array}$ & $\begin{array}{c}\text { Percent- } \\
\text { age }\end{array}$ \\
\hline Category 1 (Dissatisfied) & 31 & $58 \%$ \\
\hline Category 2 (Satisfied) & 22 & $42 \%$ \\
\hline Total Respondents & 53 & \\
\hline
\end{tabular}

ing that the benefits are outweighing the drawbacks. However, only 26 percent of the respondents have contradicting opinion. A small proportion of auditor perceives that the disadvantages of the rotation policy overshadow the advantages, as shown in Figure 1.

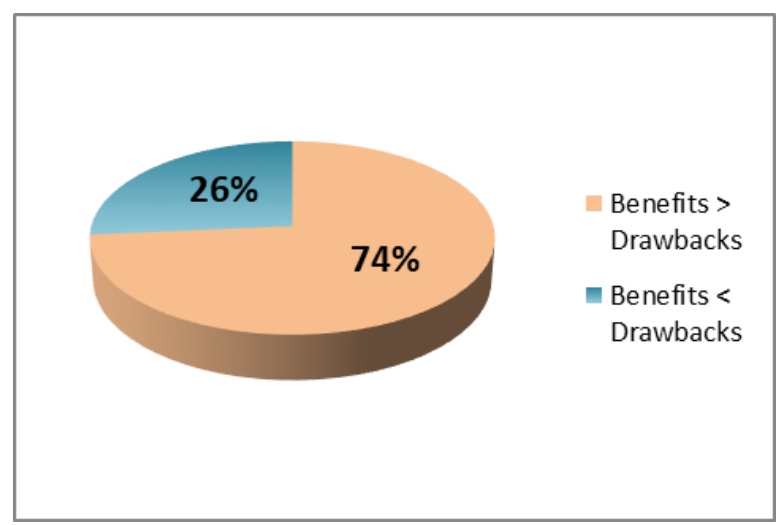

Figure 1. The Perceived Benefits and Drawbacks of Mandatory Auditor Rotation

Additionally, the respondents delivered some invaluable feedback to improve BPK's implementation of mandatory auditor rotation. The inputs, arguably, could not only enhance auditor independence in fact and appearance but also raise their satisfaction upon the policy, as shown in Figure 2.

The vast majority (59\%) of the respondents emphasize that the crucial factor in implementing mandatory auditor rotation is fairness. In other words, they urged that mandatory rotation should be equally undertaken by all auditors at every level or position in the organization. The respondents also reiterated that lack of fairness in a policy implementation would trigger jealousy among auditors and as a result, could adversely affect their performances. A fair rotation pattern, hence, should be robustly implemented. There should be no auditors who continu-

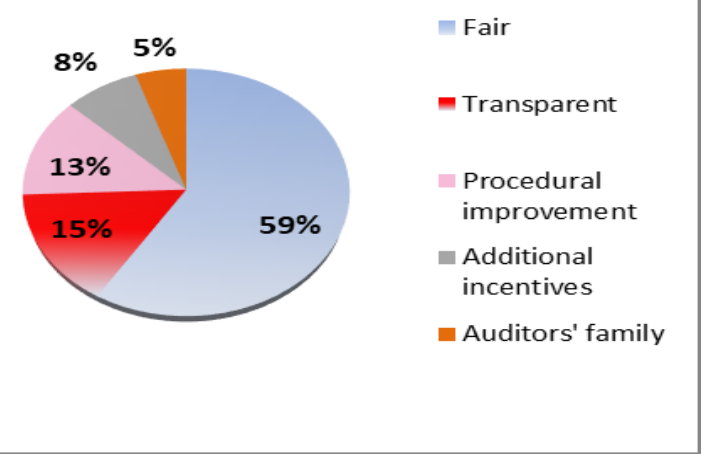

Figure 2. Respondents' Inputs to Improve the Implementation of Mandatory Rotation in BPK

ously be switched among different AKN (civil servants) in the head office in Jakarta or, contrarily, no auditors that could be transferred to provinces that are too far from their domiciles. These findings support the previous research conducted by Tan and Lau (2012). They claim that if employees see that all procedures and rules are fairly applied in a company, the job satisfaction level will be higher. As a result, it would lead to happy employees who could perform better in achieving the organization's objectives.

Similarly, 15 percent of the respondents argue that every process in determining an auditor's rotation scheme should be conducted transparently. They urge that BPK should have a grand design about the road map of the auditor rotation. The rotation design, furthermore, could benefit auditors and the institution because, firstly, it could be a tool to enhance the sense of fairness related to the rotation policy. Besides, it could be used as a media for auditors to analyze the rotation pattern and give feedback to the policymakers. Lastly, the auditors have more time to prepare their necessities if they have to be transferred to the next destination in the predetermined time.

Thirteen percent of the respondents, moreover, insist that the mandatory rotation scheme urgently needs a procedural improvement to lessen the possible drawbacks that may occur. Firstly, the respondents ar- 
gue that BPK should set a clear maximum and minimum working tenure before an auditor is transferred to another province in Indonesia. The management also needs to consider if the auditor's expertise and educational background would fit the necessities in the new office as one of the rotation requirements apart from the length of auditor tenure. Most importantly, there should be a handover of audit working paper and knowledge transfer processes, not only among the managerial level employees but also from the previous to the subsequent auditors. It could reasonably decrease the steep knowledge gap between the former and new auditors following the rotation.

Furthermore, 8 percent of the respondents point out that the rotation should be followed by additional incentives rewarded to them. The fringe benefit is intended to cover the additional cost that they have to bear because of the rotation policy. The price, moreover, could be intangible and tangible costs. The intangible loss usually comes when auditors must live far away from their families. The condition could lead to homesickness that may adversely affect the quality of auditors' work. The intangible cost, consequently, may increase the tangible expenses such as transportation costs or rental fees. Besides, auditors, who bring their family to the destination of rotation, have to pay additional costs, such as school enrollment fees for their children, rental expenses and freight charges.

The last 5 percent of the respondents, finally, suggest that the institution should take into account their family data as they are transferred to other BPK's offices. For instance, the management may consider adjusting the rotation period with the new academic term for students. Thus, it would be more convenient for parents to find new schools for the children in the new area. Although these factors are extrinsic to work, these elements are essential and could motivate employees in the working space. These also known as hygiene factors, which are physiological needs that individuals desired to be fulfilled (Herzberg, 1959 as cited in Smerek \& Peterson, 2007). If the hygiene factors are met in the workplace, it will lead to higher satisfaction and an increase in employees' performance; hence, influence the auditors' perception that the benefits of mandatory rotation exceed its drawbacks.

\section{CONCLUSION}

Mandatory auditor rotation alone may not be sufficient to enhance their independence, especially in the public sector area. The fact that a mandatory rotation scheme is a prominent debatable topic among professionals and academics reflects an inconclusive opinion on whether the policy could bring more independence to the auditors. Besides, it is notable for taking into account 'auditor satisfaction' in assessing the impact of the implementation of obligatory rotation. As the subject of the policy, auditors are the ones who could determine whether the rotation system could be fruitful for stakeholders or vice versa.

After statistically testing the primary data using the independent-samples t-test, the outcomes show that, firstly, auditors' independence in appearance will increase after the implementation of the mandatory rotation. It means that the limited tenure caused by the rotation policy would raise a public perception that auditors would independently conduct their jobs without committing any "over-cozy" relationship with their clients. Moreover, the increase of independence in appearance would be necessary for BPK as the public would trust the credibility of the institution and rely on the audit reports produced by the organization. 
On the contrary, auditors perceive that their independence in fact will not be different even though they are rotated to different representative offices. In other words, mandatory rotation alone could not be enough to improve auditors' independence in fact. Because independence in fact is a person's state of mind, which allows him to act with integrity, objectivity, and honesty; thus, the ethical standards should be upheld whenever an auditor conducts his tasks. As a result, the rotation policy should be complemented by other schemes to gain more independence in fact for auditors, such as optimizing code of ethics by conducting regular ethical training, strengthening internal control systems, and promoting a whistleblowing mechanism.

The second finding of the study shows that different levels of auditor satisfaction upon the rotation policy will differentiate their perceptions related to the benefits and drawbacks of the scheme. Auditors who are satisfied with the implementation of mandatory rotation policy in BPK will consider that the plan brings more benefits than drawbacks, and vice versa. The outcome is arguably a novel finding related to the perceived impacts of mandatory auditor rotation schemes from the viewpoint of auditor satisfaction. Since the comfort of auditors can affect their performance, it is crucial to consider improving their satisfaction level toward the implementation of the rotation mechanism. Furthermore, although some auditors are not comfortable in obeying the mandatory rotation policy, the vast majority of them strongly believe that BPK needs to implement the rotation scheme since they contend that the benefits brought by the rotation system outweigh its drawbacks.

Some valuable inputs, therefore, are given by the respondents to improve the mandatory rotation. The feedbacks are, firstly, all auditors should be treated fairly and equally under the rotation policy. Arguably, if the em- ployees consider that all procedures and rules are fairly applied in a company, the job satisfaction level will be higher. It would lead to happy employees who could perform better in achieving the organization's objectives. Moreover, BPK should develop a grand design on the road map of auditor rotation; thus, the rotation pattern is transparently communicated to all auditors. In addition to increasing the sense of fairness, the rotation road map could also be utilized as a control mechanism among auditors and policy makers in BPK.

Thirdly, some respondents suggest a robust procedural improvement in implementing the rotation. For example, setting a clear maximum and minimum working tenure before the rotations of the auditors; taking into account auditors' expertise and interest; organizing the process of knowledge transfer and handover current working papers among the predecessor and successor.

Fringe benefits also become an element to support auditor satisfaction when they have to move to other provinces in Indonesia. The additional incentives are intended to cover the extra costs incurred because of the rotation policy, such as the school enrollment fee for children, rental expenses, and freight charges. Finally, the decision-maker in BPK should take into account the data of auditors' family as a consideration before transferring them to a new destination. For example, auditors would be more comfortable moving to another province with their family, if they were provided the time of the transfer approximately coincided with the beginning of the new academic year for students.

The above factors are extrinsic to work; nevertheless, they are physiological needs that individuals desire to be fulfilled. The elements are essential and can motivate employees in the working space. On the other hand, if such factors do not exist in the 
workplace, it will lead to dissatisfaction and poor employees' performance.

The results could contribute to renew the implementation of mandatory rotation policy in BPK. The inputs from the respondents are required to redesign the rotation scheme, which will increase auditor independence and accentuates their satisfaction, which leads to higher performance. Besides, this study is expected to support the literature on how mandatory auditor rotation could affect auditor independence in fact and independence in appearance by providing empirical evidence in a public sector institution. Accordingly, Dattin (2017) argues that it is essential to enrich existing literature on how crucial it is to implement mandatory auditor rotation since evidence to corroborate the assertion needs to be collected from diverse environments. The study could also contribute by providing evidence on how auditor satisfaction affects their perceived benefits and drawbacks of the rotation scheme in the public sector area.

The limitation of this study is the limited data that is used and examined. Future research that utilizes more data from auditors with various job positions would be necessary and the feedback given from the respondents can be more rigorous. Moreover, the study is conducted in BPK; the author does not make sure if the result can be appropriately applied in other governmental audit institutions since the distinct characteristic of rotation and authority they may have.

\section{REFERENCES}

Alfayad, Z., \& Arif, L. S. M. (2017). Employee voice and job satisfaction: An application of Herzberg two-factor theory. International Review of Management and Marketing, 7(1), 150-156.

Al-Khoury, A. F., Ali, A., Al-Sharif, M., Hana- nia, J., Al-Malki, I. \& Jallad, M. (2015). Auditor independence and mandatory auditor rotation in Jordan. Intermational Business Research, 8(4), 73-82. doi:10.5539/ibr.v8n4p73

Al-Thuneibat, A. A., Issa, R. T. I. A., \& Baker, R. A. B. (2011). Do audit tenure and firm size contribute to audit quality? Managerial Auditing Journal, 26(4), 317-334. doi: 10.1108/ 02686901111124648

Anggraini, P., \& Putra, R. N. (2018). Elements which trigger employee's intention to disclose fraud via a whistleblowing system: A case study. Jurnal Tata Kelola dan Akuntabilitas Keuangan Negara, 4(2), 105-124. doi: 10.28986/ jtaken.v4i2.203

Anis, A. (2014). Auditors' perceptions of audit firm rotation impact on audit quality in Egypt. Accounting and Taxation, 8(1), 105-120.

Boon, K., McKinnon, J., \& Ross, P. (2008). Audit service quality in mandatory audit tendering: Preparer perceptions and satisfaction. Accounting Research Journal, 21(2), 93-122. doi: 10.1108/10309610810905917

BPK RI. (2010). Decree of the Secretariat General of BPK Number 366/K/XXIII.2/9/2010 concerning The Rotation of BPK's Employees (Keputusan Sekretaris Jenderal Badan Pemeriksa Keuangan Republik Indonesia Nomor 366/K/X-XIII.2/9/2010 tentang Pemindahan Pegawai Non Struktural pada Pelaksana Badan Pemeriksa Keuangan).

BPK RI. (2013). Decree of the Secretariat General of BPK Number 662/K/XXIII.2/11/2013 concerning The Rotation Pattern in BPK (Keputusan Sekretaris Jenderal Badan Pemeriksa Keuangan Republik Indonesia Nomor 662/K/X-XIII.2/11/2013 tentang Pedoman Pola Pemindahan Pemeriksa di Lingkungan Badan Pemeriksa Keuangan).

BPK RI. (2017). Decree of the Audit Board of the Republic of Indonesia Number 14/ K/I-XIII.2/9/2017 concerning the Fourth Amendment of the Decree Number 3/K/I-XIII.2/7/2014 concerning Organization Structure of the State Audit Board of the Republic of Indone- 
sia (Keputusan Badan Pemeriksa Keuangan Nomor 14/K/I-XIII.2/9/2017 tentang Perubahan Keempat atas Keputusan Badan Pemeriksa Keuangan Nomor 3/K/I-XIII.2/7/2014 tentang Organisasi dan Tata Kerja Pelaksana Badan Pemeriksa Keuangan).

BPK RI. (2018). BPK Regulation Number 4 Year 2018 concerning Code of Ethics in BPK (Peraturan BPK Nomor 4 Tahun 2018 tentang Kode Etik Badan Pemeriksa Keuangan). Retrieved from https://peraturan.bpk.go.id/Home/ Details/101834/peraturan-bpk-no-4tahun-2018

Chiang, C. (2016). Conceptualising the linkage between professional scepticism and auditor independence. Pacific Accounting Review, 28(2), 180-200. doi: 10.1108/PAR-08-2015-0034

Chu, B., \& Hsu, Y. (2018). Non-audit services and audit quality - the effect of Sarbanes-Oxley act. Asia Pacific Management Review, 23(3), 201-208. doi: 10.1016/j.apmrv.2017.07.004

Dattin, C. F. (2017). Developments in France regarding the mandatory rotation of auditors: Do they enhance auditors' independence? Accounting History, 22 (1), 44-66. doi: $10.1177 / 1032373216674968$

Fernando, G. D., Abdel-Meguid, A., \& Elder, R. J. (2010). Audit quality attributes, client size and cost of equity capital. Review of Accounting \& Finance, 9(4), 363-381.

10.1108/14757701011094571

Harris, K., \& Whisenant, S. (2012). Mandatory audit rotation: An international investigation. Retrieved from https:// pdfs.semanticscholar.org/ob84/54548 ab6be3c8c7a2567ac32848672foa358.p $\mathrm{df}$

Komalasari, N. (2016). Does the rotation of head of audit office across offices impact audit quality? Study case of the Audit Board of Republic of Indonesia. Jurnal Tata Kelola dan Akuntabilitas Keuangan Negara, 2(2), 137-150. doi: 10.28986/jtaken.v2i2.61

Law of the Republic of Indonesia Number 15 of 2006 concerning the Audit Board (Undang-Undang Nomor 15 Tahun 2006 tentang Badan Pemeriksa Keuangan). Retrieved from http:// bandung.bpk.go.id/files/2009/03/UU
-15-Tahun-2006.pdf

Lennox, C. (2014). Auditor tenure and rotation. In David Hay, W. Robert Knechel and Marleen Willekens (eds.), The Routledge Companion to Auditing. New York: Routledge, 89-106

Loke, C. H., Ismail, S., \& Fatima, A. H. (2016). The perception of public sector auditors on performance audit in Malaysia: An exploratory study. Asian $R e-$ view of Accounting, 24(1), 90-104. doi: 10.1108/ARA-12-2013-0082

Nagy, A. J. (2008). Financial information systems service providers and the internal control report. Managerial Auditing Journal, 23(6), 596-608. doi: 10.1108/02686900810882129

Nicolaescu, E. (2014). The effects of audit firm rotation on earnings quality. Economics, Management and Financial Markets, 9(1), 148-153.

Ottaway, J. (2014). Improving auditor independence in Australia: Is mandatory audit firm rotation the best option? Retrieved from https:// law.unimelb.edu.au/_data/assets/ pdf_file/0004/1709509/27OTTAWAYJoanneMandatoryAuditFirmRotationPaper2.pdf (Accessed 26 August 2019)

Roy, M. N. (2015). Statutory auditors' independence in the protection of stakeholders' interest: A perceptual study. IUP Journal of Corporate Governance, 14(1), 40-67. Retrieved from https:// search.proquest.com/ docview/1691987087? accountid $=86413$

Sinason, D. H. (2000). A study of the effects of accountability and engagement risk on auditor materiality decisions in public sector audits. Journal of Public Budgeting, Accounting \& Financial Management, 12(1), 1-21. doi: 10.1108/ JPBAFM-12-01-2000-Boo1

Siregar, S. (2013). Metode penelitian kuantitatif: Dilengkapi dengan perbandingan perhitungan manual dan SPSS. Jakarta: Kencana Prenada $\mathrm{Me}-$ dia Group.

Smerek, R. E., \& Peterson, M. (2007). Examining Herzberg's theory: Improving job satisfaction among non-academic employees at a university. Research in Higher Education, 48(2), 229-250. doi: 10.1007/s11162-006-9042-3 
Tan, S. L. C., \& Lau, C. M. (2012). The impact of performance measures on employee fairness perceptions, job satisfaction and organisational commitment. Journal of Applied Management Accounting Research, 10(2), 57-72.

Tso, G. K. F. T., Liu, F., \& Li, J. (2015). Identifying factors of employee satisfaction: A case study of Chinese resource-based state-owned enterprises. Social Indicator Research, 123(2), 567-583. doi: 10.1007/s11205-014-0750-3

Tuovila, A. (2019). Unqualified opinion. Retrieved from https:// www.investopedia.com/terms/u/ unqualified-opinion.asp

\section{APPENDICES}

Appendix 1. Research Variables in the Questioners

\begin{tabular}{|c|c|c|c|}
\hline Variables & Question Type & $\begin{array}{c}\text { Number of Ques- } \\
\text { tions }\end{array}$ & Respondents \\
\hline \multicolumn{4}{|l|}{ Auditor Satisfaction } \\
\hline Preferable destination & close-ended question & 1 & Group 2 \\
\hline Fairness and justice & close-ended question & 1 & Group 2 \\
\hline Proper incentives & close-ended question & 1 & Group 2 \\
\hline \multicolumn{4}{|l|}{ Benefits of MAR* } \\
\hline \multicolumn{4}{|l|}{ Improve auditor independence } \\
\hline \multirow[t]{2}{*}{ Independence in fact } & close-ended question & 3 & Group 1 \\
\hline & & & Group 2 \\
\hline \multirow[t]{2}{*}{ Independence in appearance } & close-ended question & 4 & Group 1 \\
\hline & & & Group 2 \\
\hline Bring fresh eyes & close-ended question & 1 & Group 2 \\
\hline Watchdog mechanism & close-ended question & 1 & Group 2 \\
\hline Incentives for auditors & close-ended question & 2 & Group 2 \\
\hline \multicolumn{4}{|l|}{ Drawbacks of MAR* } \\
\hline Limited impact on 'independence in fact' & close-ended question & 1 & Group 2 \\
\hline Increase the risk audit failure & close-ended question & 1 & Group 2 \\
\hline \multirow[t]{2}{*}{ Increase cost } & close-ended question & 1 & Group 2 \\
\hline & open-ended question & 1 & Group 2 \\
\hline Reduce specialisation and familiarity & open-ended question & 1 & Group 2 \\
\hline Benefits vs Drawbacks of MAR* & open-ended question & 4 & Group 2 \\
\hline Total Questions & & 23 & \\
\hline
\end{tabular}


Appendix 2. General Information of the Respondents

\begin{tabular}{|c|c|c|c|c|c|}
\hline \multirow{2}{*}{ Variables } & \multirow{2}{*}{ Criteria } & \multicolumn{2}{|c|}{ Group 1} & \multicolumn{2}{|c|}{ Group 2} \\
\hline & & Total & $\%$ & Total & $\%$ \\
\hline \multirow{2}{*}{ Gender } & Male & 21 & $43 \%$ & 34 & $64 \%$ \\
\hline & Female & 28 & $57 \%$ & 19 & $36 \%$ \\
\hline \multirow{4}{*}{ Age } & $20-30$ years & 45 & $92 \%$ & 3 & $6 \%$ \\
\hline & $31-40$ years & 4 & $8 \%$ & 35 & $66 \%$ \\
\hline & $41-50$ years & 0 & $0 \%$ & 14 & $26 \%$ \\
\hline & $>51$ years & 0 & $0 \%$ & 1 & $2 \%$ \\
\hline \multirow{3}{*}{$\begin{array}{l}\text { Job } \\
\text { position }\end{array}$} & Team member (Pemeriksa pertama) & 47 & $96 \%$ & 13 & $25 \%$ \\
\hline & Team leader (Pemeriksa muda) & 2 & $4 \%$ & 31 & $58 \%$ \\
\hline & Controller (Pemeriksa madya) & 0 & $0 \%$ & 9 & $17 \%$ \\
\hline \multirow{5}{*}{$\begin{array}{l}\text { Working } \\
\text { tenure } \\
\text { at BPK }\end{array}$} & $0-5$ years & 47 & $96 \%$ & 3 & $6 \%$ \\
\hline & $6-10$ years & 2 & $4 \%$ & 15 & $28 \%$ \\
\hline & $11-15$ years & 0 & $0 \%$ & 26 & $49 \%$ \\
\hline & $16-20$ years & 0 & $0 \%$ & 3 & $6 \%$ \\
\hline & $>20$ years & 0 & $0 \%$ & 6 & $11 \%$ \\
\hline \multirow{3}{*}{$\begin{array}{l}\text { Educational } \\
\text { level }\end{array}$} & DI/DIII & 0 & s & 1 & $2 \%$ \\
\hline & S1/D4 & 45 & $92 \%$ & 28 & $53 \%$ \\
\hline & $\mathrm{S} 2$ & 4 & $8 \%$ & 24 & $45 \%$ \\
\hline \multirow{5}{*}{$\begin{array}{l}\text { Number of } \\
\text { rotation } \\
\text { Experienced }\end{array}$} & Once & - & - & 18 & $34 \%$ \\
\hline & Twice & - & - & 15 & $28 \%$ \\
\hline & 3 times & - & - & 15 & $28 \%$ \\
\hline & 4 times & - & - & 2 & $4 \%$ \\
\hline & $>4$ times & - & - & 3 & $6 \%$ \\
\hline
\end{tabular}

Appendix 3. The output of independent-samples t-test to answer the Research Question 1

\begin{tabular}{clcccc}
\hline Independence & \multicolumn{1}{c}{ Auditor } & N & Mean & $\begin{array}{c}\text { Std. Devia- } \\
\text { tion }\end{array}$ & $\begin{array}{c}\text { Std. Error } \\
\text { Mean }\end{array}$ \\
\hline Independence in Fact & $\begin{array}{l}\text { Group 1 } \\
\text { (no experience of MAR*) } \\
\text { Group 2 } \\
\text { (experienced the MAR) }\end{array}$ & 49 & 11.88 & 1.986 & .284 \\
\hline $\begin{array}{c}\text { Group 1 } \\
\text { Inde experience of MAR*) } \\
\text { Appearance }\end{array}$ & $\begin{array}{l}\text { Group 2 } \\
\text { (experienced the MAR) }\end{array}$ & 43 & 11.06 & 2.538 & .349 \\
\hline
\end{tabular}




\begin{tabular}{|c|c|c|c|c|c|c|c|c|c|c|}
\hline \multicolumn{11}{|c|}{ Appendix 4. Independent-Samples test } \\
\hline & & \multicolumn{4}{|c|}{$\begin{array}{l}\text { Levene's Test } \\
\text { for equality }\end{array}$} & \multicolumn{5}{|c|}{ t-test for Equality of Means } \\
\hline & & \multirow[t]{2}{*}{$\mathrm{F}$} & \multirow[t]{2}{*}{ Sig. } & \multirow[t]{2}{*}{$\mathrm{t}$} & \multirow[t]{2}{*}{ df } & \multirow[t]{2}{*}{$\begin{array}{l}\text { Sig. (2- } \\
\text { tailed) }\end{array}$} & \multirow[t]{2}{*}{$\begin{array}{l}\text { Mean } \\
\text { Differ- } \\
\text { ence }\end{array}$} & \multirow[t]{2}{*}{$\begin{array}{l}\text { Std Error } \\
\text { Differ- } \\
\text { ence }\end{array}$} & \multicolumn{2}{|c|}{$\begin{array}{c}\text { 95\% Confidence } \\
\text { Interval of the } \\
\text { Difference }\end{array}$} \\
\hline & & & & & & & & & Lower & Upper \\
\hline \multirow[t]{2}{*}{$\begin{array}{l}\text { Independence } \\
\text { in Fact }\end{array}$} & $\begin{array}{l}\text { Equal variances } \\
\text { assumed }\end{array}$ & 3.112 & .081 & 1.809 & 100 & .073 & .821 & .454 & -.079 & 1.721 \\
\hline & $\begin{array}{l}\text { Equal variances } \\
\text { not assumed }\end{array}$ & & & .1 .827 & 97.404 & .071 & .821 & .449 & -.71 & 1.713 \\
\hline \multirow[t]{2}{*}{$\begin{array}{l}\text { Independence } \\
\text { in Appearance }\end{array}$} & $\begin{array}{l}\text { Equal variances } \\
\text { assumed }\end{array}$ & .095 & .758 & -3.459 & 100 & .001 & -1.998 & .578 & -3.144 & -.852 \\
\hline & $\begin{array}{l}\text { Equal variances } \\
\text { not assumed }\end{array}$ & & & -3.455 & 98.834 & .001 & -1.998 & .578 & -3.145 & -.850 \\
\hline
\end{tabular}

Appendix 5. The output of independent-samples t-test to answer the Research Question 2

\begin{tabular}{lllcccc}
\hline & \multicolumn{1}{c}{ Auditor Satisfaction } & N & Mean & $\begin{array}{c}\text { Std. } \\
\text { Deviation }\end{array}$ & $\begin{array}{c}\text { Std. Error } \\
\text { Mean }\end{array}$ \\
\hline \multirow{2}{*}{ Benefit } & Not satisfied & 31 & 39.74 & 5.215 & .937 & 1.022 \\
& Satisfied & 22 & 42.86 & 4.794 & 2.211 & .397 \\
\hline \multirow{2}{*}{ Drawbacks } & Not satisfied & 31 & 13.10 & 11.59 & 2.754 & .587 \\
& Satisfied & 22 & & & & \\
& & & & & &
\end{tabular}

Appendix 6. Independent-Samples test

\begin{tabular}{|c|c|c|c|c|c|c|c|c|c|c|}
\hline & & \multicolumn{2}{|c|}{$\begin{array}{c}\text { Levene's Test } \\
\text { for equality of } \\
\text { variances } \\
\end{array}$} & \multicolumn{7}{|c|}{ t-test for Equality of Means } \\
\hline & & \multirow[t]{2}{*}{$\mathrm{F}$} & \multirow[t]{2}{*}{ Sig. } & \multirow[t]{2}{*}{$\mathrm{t}$} & \multirow[t]{2}{*}{ df } & \multirow[t]{2}{*}{$\begin{array}{l}\text { Sig. (2- } \\
\text { tailed) }\end{array}$} & \multirow[t]{2}{*}{$\begin{array}{l}\text { Mean } \\
\text { Differ- } \\
\text { ence }\end{array}$} & \multirow{2}{*}{$\begin{array}{l}\text { Std } \\
\text { Error } \\
\text { Differ- } \\
\text { ence }\end{array}$} & \multicolumn{2}{|c|}{$\begin{array}{c}\text { 95\% Confidence } \\
\text { Interval of the } \\
\text { Difference }\end{array}$} \\
\hline & & & & & & & & & Lower & Upper \\
\hline \multirow[t]{2}{*}{ Benefit } & $\begin{array}{l}\text { Equal variances } \\
\text { assumed }\end{array}$ & .359 & .552 & -2.219 & 51 & .031 & -3.122 & 1.407 & -5.946 & -.298 \\
\hline & $\begin{array}{l}\text { Equal variances } \\
\text { not assumed }\end{array}$ & & & -2.252 & 47.590 & .029 & -3.122 & 1.386 & -5.910 & -.334 \\
\hline \multirow[t]{2}{*}{ Drawbacks } & $\begin{array}{l}\text { Equal variances } \\
\text { assumed }\end{array}$ & .093 & .762 & 2.205 & 51 & .032 & 1.506 & .683 & .135 & 2.877 \\
\hline & $\begin{array}{l}\text { Equal variances } \\
\text { not assumed }\end{array}$ & & & 2.124 & 38.908 & .040 & 1.506 & .709 & .072 & 2.940 \\
\hline
\end{tabular}




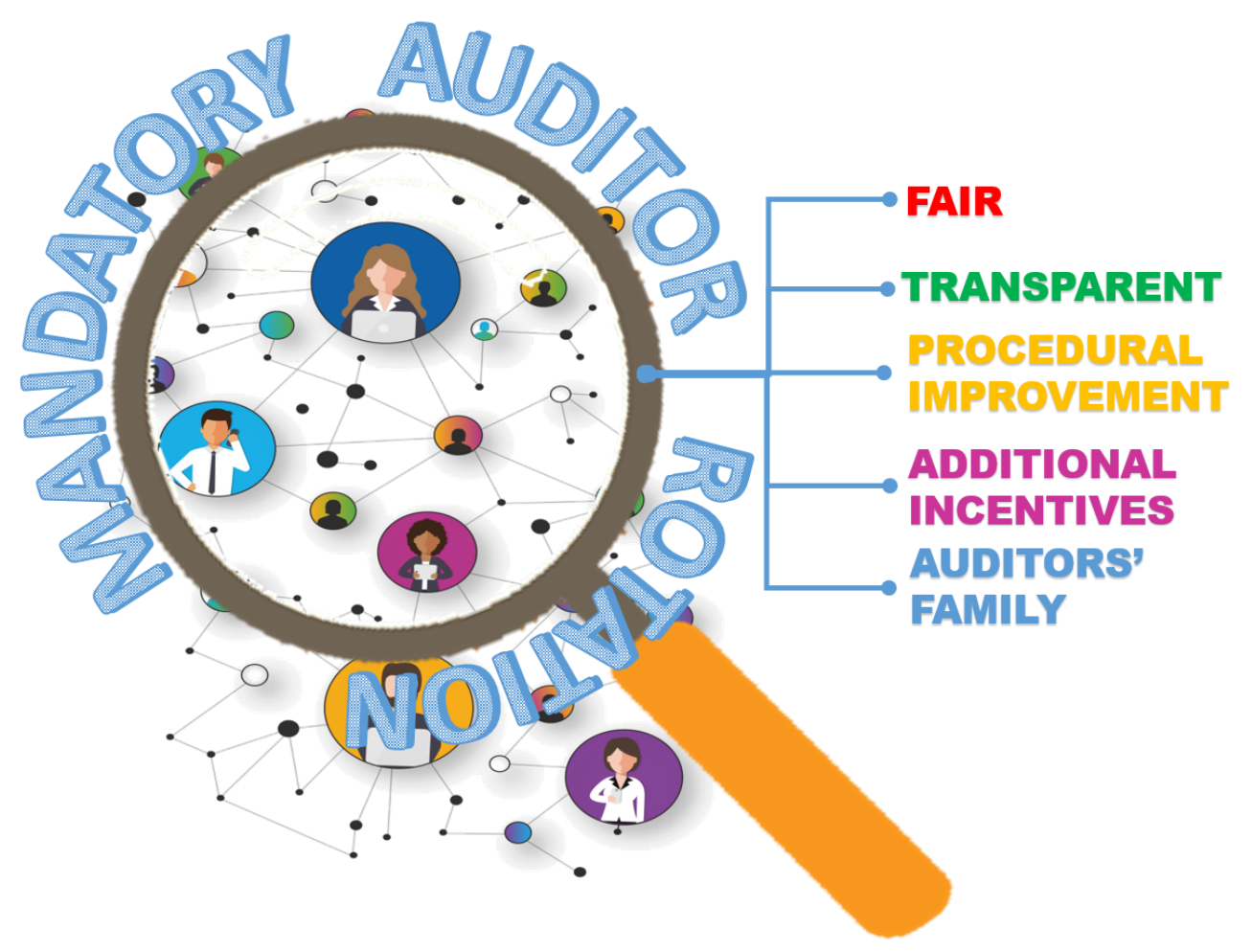

